\title{
The structure of $\alpha_{2}$-macroglobulin-methylamine after papain digestion as determined by electron microscopy
}

\author{
Isa M. HUSSAINI, Nancy L. FIGLER and Steven L. GONIAS* \\ Departments of Pathology and Biochemistry, University of Virginia Health Sciences Center, Charlottesville, VA 22908, U.S.A.
}

\begin{abstract}
$\alpha_{2}$-Macroglobulin-methylamine $\left(\alpha_{2} \mathrm{M}-\mathrm{CH}_{3} \mathrm{NH}_{2}\right)$ was digested with papain at $\mathrm{pH} 5.0$. The major $600 \mathrm{kDa}$ fragment was purified by molecular-exclusion chromatography. In a non-denaturing gel-electrophoresis system, the $600 \mathrm{kDa}$ fragment migrated in a single band at a rate that was comparable with that for the untreated $\alpha_{2} \mathrm{M}-\mathrm{CH}_{3} \mathrm{NH}_{2}$. The elution volume of the $600 \mathrm{kDa}$ fragment on Superose- 6 was slightly increased. In primary cultures of rat hepatocytes, cellular uptake of ${ }^{125} \mathrm{I}-\alpha_{2} \mathrm{M}-\mathrm{CH}_{3} \mathrm{NH}_{2}$ was not affected by the $600 \mathrm{kDa}$ fragment, confirming the results of other investigators. The $600 \mathrm{kDa}$ fragment was negatively stained with uranyl formate and analysed by transmission electron microscopy. The major structural characteristics of the parent protein $\left(\alpha_{2} \mathrm{M}-\mathrm{CH}_{3} \mathrm{NH}_{2}\right)$ remained intact. The most common image included prominent lateral walls and two centrally located regions of stain exclusion termed 'paddle structures'. The distance between the paddle structures was equivalent in $\alpha_{2} \mathrm{M}-\mathrm{CH}_{3} \mathrm{NH}_{2}$ and the $600 \mathrm{kDa}$ fragment $[\approx 13.5 \mathrm{~nm}(135 \AA)$. By contrast, the lateral walls in the $600 \mathrm{kDa}$ fragment were decreased in length by $\approx 0.37 \mathrm{~nm}(37 \AA)(19 \%)$. It is proposed that the $600 \mathrm{kDa}$ structure retains the 'hollow cylinder' shape of $\alpha_{2} \mathrm{M}-\mathrm{CH}_{3} \mathrm{NH}_{2}$. The structure of the cylinder is formed by the lateral walls and four paddle structures (only two are imaged, owing to overlapping). The paddle structures in the $600 \mathrm{kDa}$ fragment are intact and relatively closer to the apices of the molecule, owing to the decrease in lateral wall length. Since the $\alpha_{2} \mathrm{M}$ receptor-binding sites are removed by papain digestion, the studies presented here support the location of the receptor-binding sites near the apices of the lateral walls.
\end{abstract}

\section{INTRODUCTION}

$\alpha_{2}$-Macroglobulin $\left(\alpha_{2} M\right)$ is a large plasma glycoprotein $(718 \mathrm{kDa})$ that inhibits proteinases of all four major classes [1]. The native protein consists of four identical subunits [2-4]. Intersubunit disulphide bonds bridge subunit pairs, forming covalent units with a molecular mass of approx. $360 \mathrm{kDa}[2]$. Association of subunit pairs in the intact whole molecule is due to strong non-covalent interactions $[2,4]$.

Proteinases initiate a reaction with $\alpha_{2} M$ by cleaving one of a series of susceptible peptide bonds in an area of the $\alpha_{2} \mathbf{M}$ subunit termed the 'bait region' $[1,2,5]$. This interaction causes a conformational change in the $\alpha_{2} \mathrm{M}$ molecule, trapping the enzyme so that a non-dissociable complex is formed, even though the enzyme active site is regenerated. $\alpha_{2} \mathbf{M}$-proteinase complexes migrate more rapidly than the unchanged or native inhibitor in non-denaturing gel systems [5]. This finding has led to the terms 'slow form' and 'fast form' to designate the conformations of $\alpha_{2} \mathbf{M}$ before and after reaction with proteinase respectively. A similar conformational change may be induced in $\alpha_{2} \mathbf{M}$ by small primary amines such as methylamine (the resulting preparation will be referred to as ' $\alpha_{2} \mathbf{M}-\mathrm{CH}_{3} \mathrm{NH}_{2}$ ') [5,6]. Receptors for $\alpha_{2} \mathbf{M}$ present on macrophages, hepatocytes and fibroblasts recognize only the transformed conformation or fast form of $\alpha_{2} M$ (enzymeor amine-treated) [7-10].

$\alpha_{2} \mathbf{M}$ conformational change has been studied extensively by electron microscopy. For the most part these investigations have demonstrated that the slow- and fast-form structures are highly distinct. Negatively stained images of native $\alpha_{2} \mathbf{M}$ have been likened to a 'padlock' structure [11], a 'doughnut' [12,13], a tetramer of spherules [13] and, most recently, a doughnut surrounded by four spherules [14]. Considerable variability is usually evident in these electron micrographs. By contrast, fast- form $\alpha_{2} \mathbf{M}$ yields a readily reproducible and rather consistently oriented negatively stained image [11-14]. The structure basically resembles the letter ' $H$ ', although the central bar connecting the lateral arms may not be prominent [15]. A single small circular region of stain exclusion (termed the 'paddle structure' in the present paper) is usually observed on either side of the 'hypothetical' central bar [15,16]. $\alpha_{2} \mathbf{M}$-proteinase and $\alpha_{2} \mathrm{M}-\mathrm{CH}_{3} \mathrm{NH}_{2}$ are not significantly different in negatively stained preparations, although the proteinase may be identified centrally in the inhibitor structure in some cases $[15,16]$.

At $\mathrm{pH} 4.5-5.0, \alpha_{2} \mathrm{M}-\mathrm{CH}_{3} \mathrm{NH}_{2}$ is cleaved by papain, causing the release of an $18 \mathrm{kDa}$ fragment from the $C$-terminus of each subunit [17]. A proteinase isolated from the bacterium Lysobacter enzymogenes causes a similar change in the structure of $\alpha_{2} \mathrm{M}-\mathrm{CH}_{3} \mathrm{NH}_{2}$ [18]. In both cases, cell-surface receptor-binding activity co-purifies with the small $18 \mathrm{kDa}$ fragment; however, the affinity is significantly reduced [17-19]. The residual $600 \mathrm{kDa}$ portion of $\alpha_{2} \mathrm{M}-\mathrm{CH}_{3} \mathrm{NH}_{2}$ retains no affinity for the $\alpha_{2} \mathrm{M}$ receptor, as determined in experiments with cells in culture or in vivo in mice [17-19].

By using immuno-electron microscopy, the location of the $\alpha_{2} \mathbf{M}$ receptor-binding site has been identified near the four tips of the lateral walls in the transformed $H$ structure [20]. If the acidic proteinase treatments truly cause dissociation of the receptor-binding domains in $\alpha_{2} \mathrm{M}-\mathrm{CH}_{3} \mathrm{NH}_{2}$, then the $18 \mathrm{kDa}$ fragments should represent the apices of the lateral walls, as suggested by the antibody studies. In the present investigation the structure of the $600 \mathrm{kDa}$ fragment $\left(\alpha_{2} \mathrm{M}-\mathrm{CH}_{3} \mathrm{NH}_{2}\right.$ after papain digestion) has been studied by electron microscopy, f.p.l.c., native gel electrophoresis and receptor-binding experiments. Our studies indicate that the major features of the $\alpha_{2} \mathrm{M}-\mathrm{CH}_{3} \mathrm{NH}_{2}$ structure remain intact after papain digestion, without evidence of denaturation. A significant decrease in the

Abbreviations used : $\alpha_{2} \mathrm{M}-\mathrm{CH}_{3} \mathrm{NH}_{2}, \alpha_{2}$-macroglobulin-methylamine; EBSS, Earle's balanced salts solution; PBS, 20 mM-sodium phosphate/150 mM$\mathrm{NaCl}, \mathrm{pH}$ 7.4.

* To whom correspondence and reprint requests should be sent. 
length of the lateral walls was measured. By contrast, the structure of the two paddles and the distance between the paddles was not changed.

\section{MATERIALS AND METHODS}

\section{Materials}

Iodoacetamide and $\mathrm{CH}_{3} \mathrm{NH}_{2}$ were purchased from Sigma (St. Louis, MO, U.S.A.). Electrophoresis reagents were purchased from Bio-Rad (Richmond, CA, U.S.A.). Papain was purchased from Sigma. Human $\alpha_{2} \mathbf{M}$ was purified from plasma by the method of Kurecki et al. [21] as modified by Imber \& Pizzo [7]. $\alpha_{2} \mathrm{M}$ was modified with $\mathrm{CH}_{3} \mathrm{NH}_{2}$ by dialysing the native inhibitor against $200 \mathrm{~mm}-\mathrm{CH}_{3} \mathrm{NH}_{2} / 50 \mathrm{~mm}-\mathrm{Tris} / \mathrm{HCl}, \mathrm{pH} 8.2$, for $6 \mathrm{~h}$ at $22^{\circ} \mathrm{C}$ and then exhaustively against $20 \mathrm{~mm}$-sodium phosphate/ $150 \mathrm{~mm}-\mathrm{NaCl}, \mathrm{pH} 7.4$ (PBS) at $4{ }^{\circ} \mathrm{C}$.

\section{Digestion of $\alpha_{2} \mathrm{M}-\mathrm{CH}_{3} \mathrm{NH}_{2}$ with papain}

$\alpha_{2} \mathrm{M}-\mathrm{CH}_{3} \mathrm{NH}_{2}(6.0 \mathrm{mg})$ was dialysed against $100 \mathrm{~mm}$-sodium acetate and then allowed to react with papain $(0.3 \mathrm{mg})$ in $50 \mathrm{~mm}$ sodium acetate/1.0 mM-cysteine, $\mathrm{pH}$ 5.0. After incubation for $20 \mathrm{~h}$ at $22^{\circ} \mathrm{C}$, the $\mathrm{pH}$ of the solution was raised to 7.5 by the addition of Tris $/ \mathrm{HCl}, \mathrm{pH} 8.0$. Iodoacetamide $(5.0 \mathrm{~mm})$ was added to inactivate the papain. After $30 \mathrm{~min}$, the reaction mixture was fractionated on Ultrogel AcA-22 $(1.0 \mathrm{~cm} \times 50 \mathrm{~cm})$ in PBS.

Papain-treated $\alpha_{2} \mathrm{M}-\mathrm{CH}_{3} \mathrm{NH}_{2}$ was analysed by size-exclusion chromatography on a pre-packed Superose-6 column (Pharmacia LKB Biotechnology, Piscataway, NJ, U.S.A.) using a Perkin-Elmer LC system equipped with a diode-array detector (LC-235) coupled to a Gibson fraction collector (FC 203). The chromatography buffer was PBS and the flow rate was $0.4 \mathrm{ml} / \mathrm{min}$. The void volume $\left(V_{0}\right)$ of the column was $6.40 \mathrm{ml}$ as estimated with Blue Dextran $(2000 \mathrm{kDa})$. The total accessible volume, defined as the sum of $V_{\mathrm{o}}$ and the pore volume, was $19.7 \mathrm{ml}$ as determined with $\mathrm{NaN}_{3}$.

\section{PAGE}

Chromatography fractions were analysed by SDS/PAGE under reducing and non-reducing conditions using the imidazole/Hepes, pH 7.5, buffer system described by McLellan [22] and modified by Gonias et al. [23].

F.p.l.c.-purified native $\alpha_{2} \mathrm{M}, \alpha_{2} \mathrm{M}-\mathrm{CH}_{3} \mathrm{NH}_{2}$ and papain-treated $\alpha_{2} \mathrm{M}-\mathrm{CH}_{3} \mathrm{NH}_{2}$ were subjected to native gel electrophoresis at pH 7.5 [22]. The gel was stained with $0.25 \%$ (w/v) Coomassie Brilliant Blue R-250 in methanol/acetic acid/water $(4: 1: 5$, by vol.).

\section{Radioiodination}

$\alpha_{2} \mathrm{M}-\mathrm{CH}_{3} \mathrm{NH}_{2}$ was radioiodinated with $\mathrm{Na}^{125} \mathrm{I}$ (Amersham) using Iodobeads as described by the manufacturer (Pierce Chemical Co.). The specific radioactivity was $2.0 \mu \mathrm{Ci} / \mu \mathrm{g}$.

\section{Binding studies}

Primary cultures of hepatocytes were prepared by using Sprague-Dawley rats as previously described [24]. The cells were cultured in $35 \mathrm{~mm}$-diameter collagen-coated plates $(15 \mu \mathrm{g}$ of collagen/well). Before starting an experiment, the wells were washed twice with Earle's balanced salts solution (EBSS) with

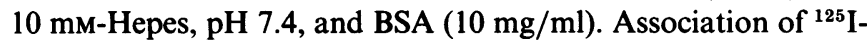
$\alpha_{2} \mathrm{M}-\mathrm{CH}_{3} \mathrm{NH}_{2}(1 \mathrm{nM})$ with hepatocytes was studied at $37^{\circ} \mathrm{C}$ in the presence of different concentrations $(0.2-200 \mathrm{nM})$ of unlabelled $\alpha_{2} \mathrm{M}-\mathrm{CH}_{3} \mathrm{NH}_{2}$ or $600 \mathrm{kDa}$ fragment. After $3 \mathrm{~h}$, incubations were terminated by separating the medium from the cells. The cells were washed three times with EBSS/Hepes, pH 7.4 and lysed with $0.1 \mathrm{M}-\mathrm{NaOH} / 2.5 \%$ (w/v) SDS. Cellassociated radioactivity was determined in a $\gamma$-radiation counter.
This procedure has been described in greater detail elsewhere [24].

\section{Electron microscopy}

Solutions of $\alpha_{2} \mathrm{M}(50 \mu \mathrm{g} / \mathrm{ml})$ were adsorbed on thin carbon films for $1 \mathrm{~min}$. The films were then transferred to $2.0 \%$ glutaraldehyde for $10 \mathrm{~min}$ and washed extensively with deionized water. Films were stained with $2.0 \%$ uranyl formate for $60 \mathrm{~s}$, transferred to 300-mesh nickel hexagon grids and air-dried at $28^{\circ} \mathrm{C}$.

Air-dried grids were analysed by conventional transmission electron microscopy using a Zeiss 902 electron microscope at $80 \mathrm{kV}$. All photomicrographs were obtained at a direct magnification of $\times 148000$ and $\times 240000$.

\section{Image analysis}

Photomicrograph negatives obtained at a direct magnification of $\times 148000$ were enlarged 2.5 times to form positive prints. Measurements were then made using the prints and a Laboratory Computer Systems Micro-Plan II Image Analyzer. The reported values represent the mean \pm 1 S.D. $(n=25)$. Statistical significance was determined using the Student $t$ test for paired data.

\section{RESULTS}

\section{Chromatography of papain-digested $\alpha_{2} \mathrm{M}-\mathrm{CH}_{3} \mathrm{NH}_{2}$}

Fractionation of papain-treated $\alpha_{2} \mathrm{M}-\mathrm{CH}_{3} \mathrm{NH}_{2}$ on Ultrogel AcA 22 yielded two major peaks. As determined by SDS/PAGE (results not shown), these peaks corresponded to the $600 \mathrm{kDa}$ and $18 \mathrm{kDa}$ fragments described by Sottrup-Jensen et al. [17]. The $600 \mathrm{kDa}$ and $18 \mathrm{kDa}$ fragments were analysed by f.p.l.c. using a Superose- 6 column. The mean elution volume of the $600 \mathrm{kDa}$ fragment $(10.88 \pm 0.12 \mathrm{ml}, n=4)$ was slightly increased compared with that of $\alpha_{2} \mathrm{M}-\mathrm{CH}_{3} \mathrm{NH}_{2}$ before reaction with papain $(10.51 \pm 0.04 \mathrm{ml})$.

\section{Native gel electrophoresis}

$\alpha_{2} \mathrm{M}-\mathrm{CH}_{3} \mathrm{NH}_{2}$, the $600 \mathrm{kDa}$ fragment and native $\alpha_{2} \mathrm{M}$ were subjected to native gel electrophoresis (Fig. 1). $\alpha_{2} \mathrm{M}-\mathrm{CH}_{3} \mathrm{NH}_{2}$ demonstrated the well-characterized increase in mobility relative to native $\alpha_{2} \mathrm{M}$. The $600 \mathrm{kDa}$ fragment migrated as a single defined band. The mobility was comparable with that of $\alpha_{2} \mathrm{M}-\mathrm{CH}_{3} \mathrm{NH}_{2}$.

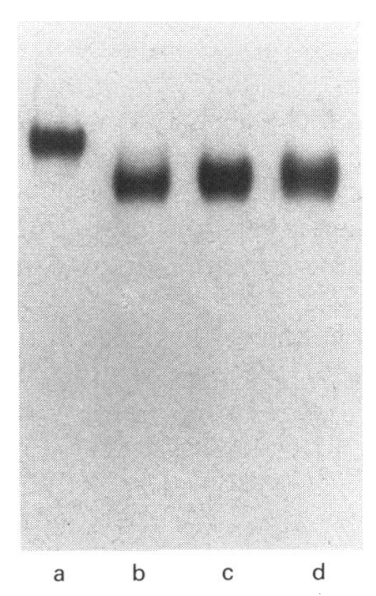

Fig. 1. PAGE of the $600 \mathrm{kDa}$ fragment

Electrophoresis was under non-denaturing conditions. Lane a, native $\alpha_{2} \mathrm{M}$; lane b, $\alpha_{2} \mathrm{M}-\mathrm{CH}_{3} \mathrm{NH}_{2}$; lane $\mathrm{c} ; \alpha_{2} \mathrm{M}$-trypsin; and lane $\mathrm{d}$, $600 \mathrm{kDa}$ fragment. 

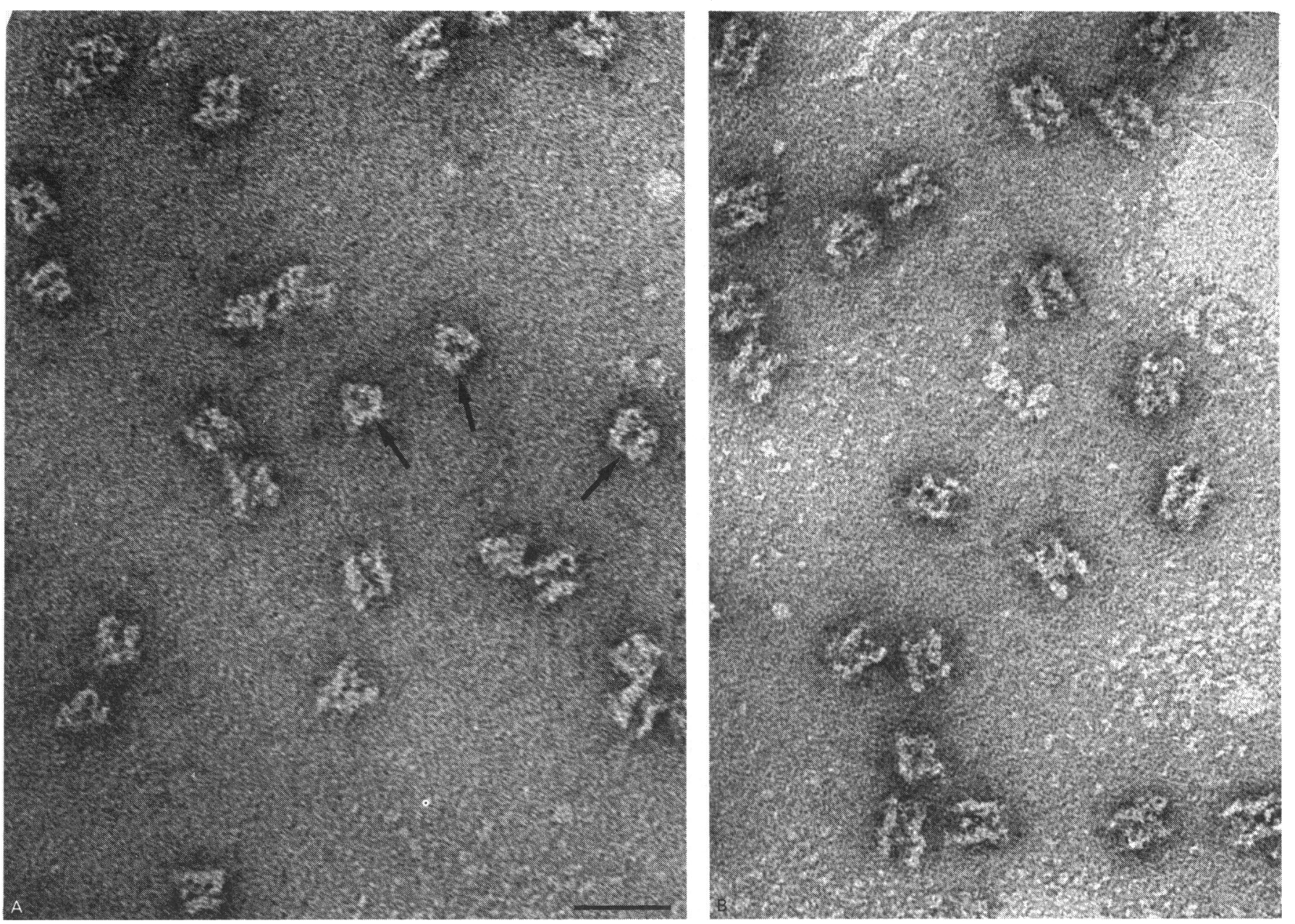

Fig. 2. Electron micrographs of $\alpha_{2} \mathrm{M}-\mathrm{CH}_{3} \mathrm{NH}_{2}$ and the $600 \mathrm{kDa}$ fragment

The $600 \mathrm{kDa}$ fragment is shown in panel A. $\alpha_{2} \mathrm{M}-\mathrm{CH}_{3} \mathrm{NH}_{2}$ is shown in panel B. The bar represents $25 \mathrm{~nm}$.

\section{Association of $\alpha_{2} \mathrm{M}-\mathrm{CH}_{3} \mathrm{NH}_{2}$ and $600 \mathrm{kDa}$ fragment with hepatocytes}

Previous investigators have demonstrated that the $600 \mathrm{kDa}$ fragment does not interact with the $\alpha_{2} \mathrm{M}$ receptor $[17,19]$. As an additional control for our preparation, ${ }^{125} \mathrm{I}-\alpha_{2} \mathrm{M}-\mathrm{CH}_{3} \mathrm{NH}_{2}$
$(1.0 \mathrm{nM})$ was incubated with hepatocytes in the presence of $\alpha_{2} \mathrm{M}-\mathrm{CH}_{3} \mathrm{NH}_{2}$ or the $600 \mathrm{kDa}$ fragment. No decrease in cellassociated radioactivity was detected with the $600 \mathrm{kDa}$ fragment at concentrations up to $200 \mathrm{~nm}$ after incubation for $3 \mathrm{~h}$ at $37^{\circ} \mathrm{C}$. Under equivalent conditions, $200 \mathrm{nM}-\alpha_{2} \mathrm{M}-\mathrm{CH}_{3} \mathrm{NH}_{2}$ decreased cell-associated radioactivity by $70 \%$.
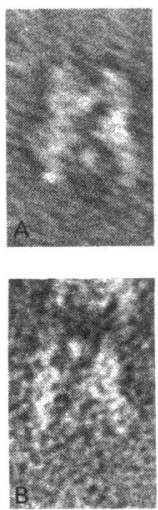
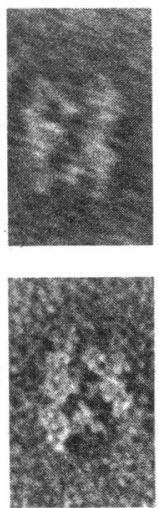
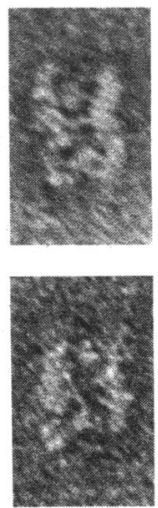
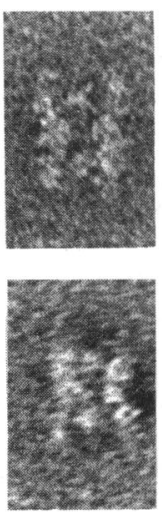
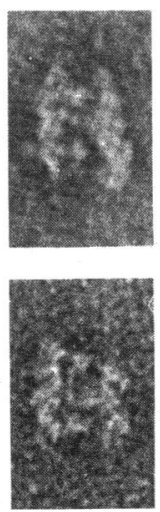
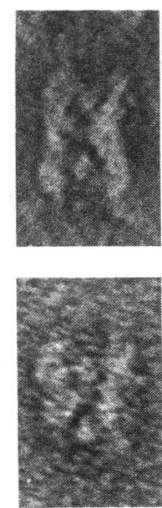
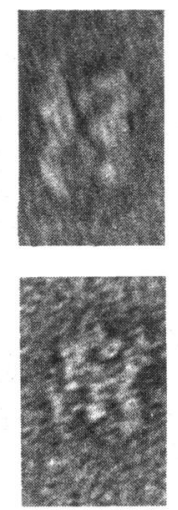
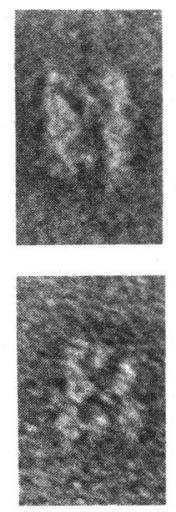
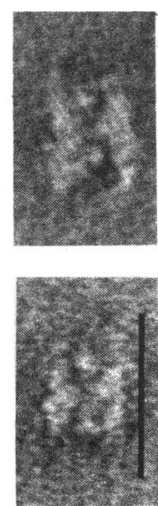

Fig. 3. High-magnification composite of $\alpha_{2} \mathrm{M}-\mathrm{CH}_{3} \mathrm{NH}_{2}$ and the $600 \mathrm{kDa}$ fragment

Molecules were selected based on apparent similarity in orientation relative to carbon film and the electron beam. $\alpha_{2} \mathrm{M}-\mathrm{CH}_{3} \mathrm{NH}$ A. The $600 \mathrm{kDa}$ fragment is shown in row B. These representative examples were selected from three different preparations. The bar represents $25 \mathrm{~nm}$. 


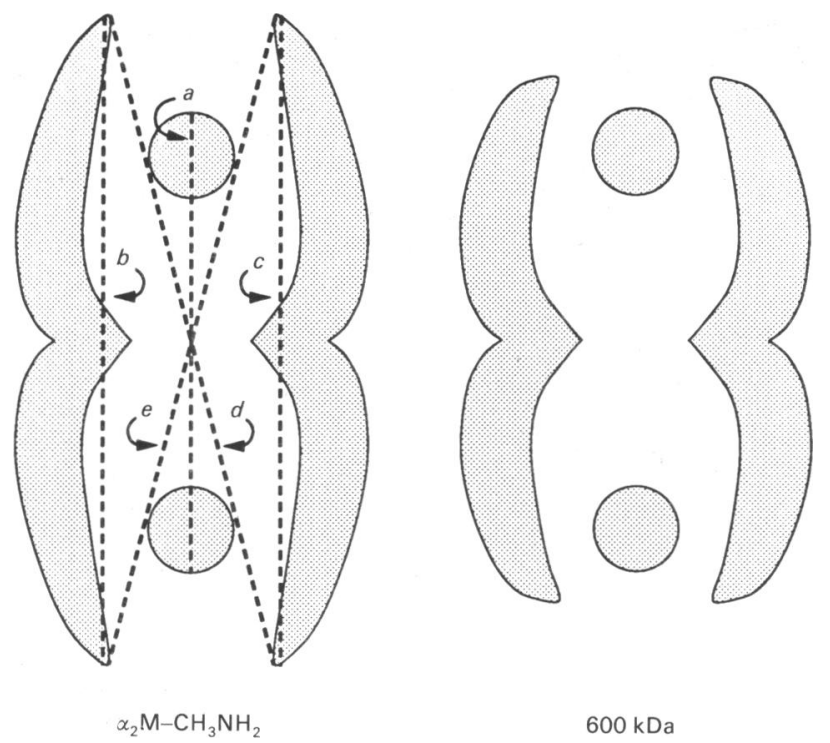

Fig. 4. Scale diagrams of $\alpha_{2} \mathrm{M}-\mathrm{CH}_{3} \mathrm{NH}_{2}$ and the $600 \mathrm{kDa}$ fragment

Easily identified molecular landmarks were utilized to measure intramolecular distances in $\alpha_{2} \mathrm{M}-\mathrm{CH}_{3} \mathrm{NH}_{2}$ and the $600 \mathrm{kDa}$ fragment. The letters $(a-e)$ demonstrate the measurements made on either form of $\alpha_{2} M$. These letters correspond to the parameters listed in Table 1. On the basis of the measurements presented in Table 1, the distance between paddles (parameter $a$ ) and the length of the lateral walls (parameters $b$ and $c$ ) in both $\alpha_{2} \mathrm{M}-\mathrm{CH}_{3} \mathrm{NH}_{2}$ and the $600 \mathrm{kDa}$ fragment have been drawn to scale.

Table 1. Measurements of $\alpha_{2} \mathrm{M}-\mathrm{CH}_{3} \mathrm{NH}_{2}$ and the $600 \mathrm{kDa}$ fragment

The parameters measured are those described in Fig. 4. Note $1 \AA$ $=0.1 \mathrm{~nm}$ (SI unit).

\begin{tabular}{lcc}
\hline & \multicolumn{2}{c}{ Value } \\
\cline { 2 - 3 } Parameter & $\alpha_{2} \mathrm{M}-\mathrm{CH}_{3} \mathrm{NH}_{2}$ & $600 \mathrm{kDa}$ fragment \\
\hline$a$ & $133.9 \pm 8.0 \AA$ & $136.4 \pm 8.5 \AA$ \\
$\frac{1}{2}(b+c)$ & $191.7 \pm 7.1 \AA \AA$ & $154.5 \pm 9.2 \AA$ \\
$\frac{1}{2}(d+e)$ & $212.0 \pm 8.5 \AA$ & $181.9 \pm 6.9 \AA$ \\
$\frac{1}{2}(b+c) / a$ & $1.44 \pm 0.11$ & $1.13 \pm 0.08$ \\
$\frac{1}{2}(d+e) / a$ & $1.59 \pm 0.14$ & $1.34 \pm 0.11$ \\
\hline
\end{tabular}

\section{Electron-microscopy studies}

Papain-treated $\alpha_{2} \mathrm{M}-\mathrm{CH}_{3} \mathrm{NH}_{2}$ retained many of the characteristics of the parent molecule, as determined by electron microscopy (Fig. 2). The prominent lateral walls were still present and readily identified when the $\alpha_{2} \mathbf{M}$ was properly oriented. The paddle structures in the centre of the hypothetical 'hollow cylinder' appeared unchanged.

Many of the $600 \mathrm{kDa}$ molecules oriented on the carbon film so that the length of the cylinder was parallel to the electron beam (arrows in Fig. 2, panel A). The resulting image was an irregular 'doughnut'. Close examination revealed that the 'doughnutlike' image was probably formed by the two lateral walls and the paddle structures (the external structure of the cylinder).

When papain-treated and untreated $\alpha_{2} \mathrm{M}-\mathrm{CH}_{3} \mathrm{NH}_{2}$ were oriented comparably, the lateral walls in the $600 \mathrm{kDa}$ fragment were significantly shorter. This is most easily appreciated in the high-magnification composite shown in Fig. 3. In control experiments, $\alpha_{2} \mathrm{M}-\mathrm{CH}_{3} \mathrm{NH}_{2}$ was treated with $5.0 \mathrm{~mm}$ iodocetamide for $30 \mathrm{~min}$ (no papain). The alkylating agent did not affect the image of $\alpha_{2} \mathrm{M}-\mathrm{CH}_{3} \mathrm{NH}_{2}$ in negatively stained preparations.

Measurements were made on 25 views each of $\alpha_{2} \mathrm{M}-\mathrm{CH}_{3} \mathrm{NH}_{2}$ and the $600 \mathrm{kDa}$ fragment as shown diagrammatically in Fig. 4. The distance between the paddles in each molecule was determined to control for differences in projection (molecular angle relative to electron beam). For both the $600 \mathrm{kDa}$ fragment and $\alpha_{2} \mathrm{M}-\mathrm{CH}_{3} \mathrm{NH}_{2}$, the average distance between paddles was equivalent $[\approx 13.5 \mathrm{~nm}(135 \AA)]$. By contrast, the lateral arms in the $600 \mathrm{kDa}$ fragment were decreased in length by $19 \%$ $[\approx 3.7 \mathrm{~nm} \quad(37 \AA)], \quad P<0.001)$. Table 1 summarizes the measurements made with $\alpha_{2} \mathrm{M}-\mathrm{CH}_{3} \mathrm{NH}_{2}$ and the $600 \mathrm{kDa}$ fragment. When the average wall length in each molecule was divided by the distance between paddles, the $600 \mathrm{kDa}$ fragment and $\alpha_{2} \mathrm{M}-\mathrm{CH}_{3} \mathrm{NH}_{2}$ remained significantly different $(P<0.001)$. The models shown in Fig. 4 have been drawn to scale on the basis of the measurements listed in Table 1.

\section{DISCUSSION}

The $\alpha_{2} \mathrm{M}$ receptor recognizes $\alpha_{2} \mathrm{M}-\mathrm{CH}_{3} \mathrm{NH}_{2}$ and $\alpha_{2} \mathrm{M}$-proteinase complexes, but not native (slow form) $\alpha_{2} \mathbf{M}[7,10]$. Digestion of $\alpha_{2} \mathrm{M}-\mathrm{CH}_{3} \mathrm{NH}_{2}$ with papain under acidic conditions causes the dissociation of the inhibitor into $600 \mathrm{kDa}$ and $18 \mathrm{kDa}$ fragments [17]. It has been proposed that the $18 \mathrm{kDa}$ fragment includes the region that is recognized by the $\alpha_{2} \mathbf{M}$ receptor $[17,18]$. The $600 \mathrm{kDa}$ fragment retains no affinity for the receptor $[17,19]$. On the basis of immunoelectron-microscopic studies [20], the $18 \mathrm{kDa}$ fragments should be located near the four apices of the lateral walls. It is also possible that the $600 \mathrm{kDa}$ fragment loses receptor affinity because of irreversible denaturation during papain digestion.

The present study confirms and extends previous investigations of the $\alpha_{2} M$ receptor-binding domains by providing images of the $600 \mathrm{kDa}$ fragment. The following conclusions are offered. After papain treatment, the basic structure of the transformed or fastform $\alpha_{2} \mathbf{M}$ remains intact. This structure is most simply described as a hollow cylinder. The body of the cylinder is composed of the two lateral walls that extend the total length of the molecule. The lateral walls do not meet to form a uniform cylinder shape. In the gaps between the walls, the major stain-excluding structures are the paddles. With proper orientation, bound proteinases may be viewed centrally through the gaps in the walls, overlapping the paddles $[15,16]$.

As might be predicted by previous immunoelectron-microscopic studies [20], the lateral walls in the $600 \mathrm{kDa}$ fragment are significantly decreased in length. In other words, the epitopes in $\alpha_{2} \mathrm{M}-\mathrm{CH}_{3} \mathrm{NH}_{2}$ recognized by 'receptor recognition site-specific' monoclonal antibodies are absent after papain digestion. Regions of $\alpha_{2} \mathrm{M}-\mathrm{CH}_{3} \mathrm{NH}_{2}$ that are preserved in the $600 \mathrm{kDa}$ fragment probably do not contribute affinity to the receptor-binding interaction. Most notably, the paddle structures are not part of the $18 \mathrm{kDa}$ fragments and probably do not bind to the receptor.

The f.p.l.c. data and electron micrographs presented here suggest that the molecular radius (apparent Stokes radius) of papain-treated $\alpha_{2} \mathrm{M}-\mathrm{CH}_{3} \mathrm{NH}_{2}$ is decreased compared with the parent molecule. We propose that the change in molecular shape may explain the heterogeneity in orientation of the $600 \mathrm{kDa}$ fragment on the carbon films. After papain digestion, many of the molecules formed images that resembled doughnuts. This structure should not be confused with the 'doughnut-like' images described for native or slow-form $\alpha_{2} \mathbf{M}$ [11-14]. The structure of native $\alpha_{2} M$ remains unclear; however, it is unlikely that the native $\alpha_{2} \mathbf{M}$ doughnut is a cylinder oriented parallel to the electron beam, as described for the $600 \mathrm{kDa}$ fragment in this study. Therefore the similar images obtained in some electron 
micrographs of native $\alpha_{2} \mathrm{M}$ and some projections of the $600 \mathrm{kDa}$ fragment probably represent very different structures.

This work was supported by a Grant-In-Aid from the American Heart Association and the Pew Scholars Program in the Biomedical Sciences. S.LG. is the recipient of NHLBI Research Career Development Award HL-02272.

\section{REFERENCES}

1. Barrett, A. J. \& Starkey, P. M. (1973) Biochem. J. 133, 709-724

2. Harpel, P. C. (1973) J. Exp. Med. 138, 508-521

3. Sottrup-Jensen, L., Stepanik, T. M., Kristensen, T. E., Wierzbicki, D. M., Jones, C. M., Lonblad, P. B., Magnusson, S. \& Petersen, T. E. (1984) J. Biol. Chem. 259, 8318-8329

4. Hall, P. K. \& Roberts, R. C. (1978) Biochem. J. 173, 27-38

5. Barrett, A. J., Brown, M. A. \& Sayers, C. A. (1979) Biochem. J. 181, $401-418$

6. Gonias, S. L., Reynolds, J. A. \& Pizzo, S. V. (1982) Biochim. Biophys. Acta 705, 306-314

7. Imber, M. J. \& Pizzo, S. V. (1981) J. Biol. Chem. 256, 8134-8139

8. Kaplan, J., Ray, F. H. \& Keogh, E. (1981) J. Biol. Chem. 256, 7705-7707

9. Van Leuven, F., Cassiman, J. J. \& Van den Berghe, H. (1979) J. Biol. Chem. 254, 5155-5160

Received 16 January 1990/27 February 1990; accepted 28 March 1990
10. Pizzo, S. V. \& Gonias, S. L. (1984) in The Receptors (Conn, P. M., ed.), vol. 1, pp. 178-221, Academic Press, New York

11. Bretaudiere, J.-P., Tapon-Bretaudiere, J. \& Stoops, J. K. (1988) Proc. Natl. Acad. Sci. U.S.A. 85, 1437-1441

12. Nishigai, M., Osada, T. \& Ikai, A. (1985) Biochim. Biophys. Acta 831, 236-241

13. Tapon-Bretaudiere, J., Bros, A., Courture-Tosi, E. \& Delain, E. (1985) EMBO J. 4, 85-89

14. Gonias, S. L. \& Figler, N. L. (1989) J. Biol. Chem. 264, 9565-9570

15. Boissett, N., Taveau, J. C., Pochon, F., Tardieu, A., Barray, M., Lamy, J. N. \& Delain, E. (1989) J. Biol. Chem. 264, 12046-12052

16. Gonias, S. L., Allietta, M. M., Pizzo, S. V., Castellino, F. J. \& Tillack, T. W. (1988) J. Biol. Chem. 263, 10903-10906

17. Sottrup-Jensen, L., Gliemann, J. \& Van Leuven, F. (1986) FEBS Lett. 205, 20-24

18. Van Leuven, F., Marynen, P., Sottrup-Jensen, L., Cassiman, J. J. \& Van den Berghe, H. (1986) J. Biol. Chem. 261, 11369-11373

19. Roche, P. A., Strickland, D. K., Enghild, J. J. \& Pizzo, S. V. (1988) J. Biol. Chem. 263, 6715-6721

20. Delain, E., Barray, M., Tapon-Bretaudiere, J., Pochon, F., Marynen, P., Cassiman, J. J., Van den Berghe, H. \& Van Leuven, F. (1988) J. Biol. Chem. 263, 2981-2989

21. Kurecki, T., Kress, L. F. \& Laskowski, M., Sr. (1979) Anal. Biochem. 99, 415-420

22. McLellan, T. (1982) Anal. Biochem. 126, 94-100

23. Gonias, S. L., Swaim, M. W., Massey, M. F. \& Pizzo, S. V. (1988) J. Biol. Chem. 263, 393-398

24. Gonias, S. L., Braud, L. L., Geary, W. A. \& Vandenberg, S. R. (1989) Blood 74, 729-736 